\title{
Presynaptic active zone density during development and synaptic plasticity
}

\author{
Gwenaëlle L. Clarke ${ }^{\dagger}$, Jie Chen ${ }^{\dagger}$ and Hiroshi Nishimune* \\ Department of Anatomy and Cell Biology, University of Kansas Medical School, Kansas City, KS, USA
}

Edited by:

Robert W. Burgess, The Jackson

Laboratory, USA

\section{Reviewed by:}

Aaron DiAntonio, Washington

University, USA

Kevin Seburn, The Jackson

Laboratory, USA

\section{*Correspondence:}

Hiroshi Nishimune, Department of Anatomy and Cell Biology, University of Kansas Medical School, 3901 Rainbow BIvd., MS 3051, HLSIC Room 2073, Kansas City, KS 66160, USA.

e-mail: hnishimune@kumc.edu

${ }^{\dagger}$ Gwenaëlle L. Clarke and Jie Chen have contributed equally to this work.
Neural circuits transmit information through synapses, and the efficiency of synaptic transmission is closely related to the density of presynaptic active zones, where synaptic vesicles are released. The goal of this review is to highlight recent insights into the molecular mechanisms that control the number of active zones per presynaptic terminal (active zone density) during developmental and stimulus-dependent changes in synaptic efficacy. At the neuromuscular junctions (NMJs), the active zone density is preserved across species, remains constant during development, and is the same between synapses with different activities. However, the NMJ active zones are not always stable, as exemplified by the change in active zone density during acute experimental manipulation or as a result of aging. Therefore, a mechanism must exist to maintain its density. In the central nervous system (CNS), active zones have restricted maximal size, exist in multiple numbers in larger presynaptic terminals, and maintain a constant density during development. These findings suggest that active zone density in the CNS is also controlled. However, in contrast to the NMJ, active zone density in the CNS can also be increased, as observed in hippocampal synapses in response to synaptic plasticity. Although the numbers of known active zone proteins and protein interactions have increased, less is known about the mechanism that controls the number or spacing of active zones. The following molecules are known to control active zone density and will be discussed herein: extracellular matrix laminins and voltage-dependent calcium channels, amyloid precursor proteins, the small GTPase Rab3, an endocytosis mechanism including synaptojanin, cytoskeleton protein spectrins and $\beta$-adducin, and a presynaptic web including spectrins. The molecular mechanisms that organize the active zone density are just beginning to be elucidated.

Keywords: bassoon, calcium channel, laminin, Rim1, spectrin, Rab3, Unc-51, synaptojanin

\section{INTRODUCTION}

Active zones were identified by electron microscopy as the electron dense thickening of the presynaptic where synaptic vesicles accumulate and dock and the area apposing the postsynaptic specialization (Couteaux and Pecot-Dechavassine, 1970; Hirokawa and Heuser, 1982; Harlow et al., 2001; Nagwaney et al., 2009). The active zone is the synaptic vesicle release site (Couteaux and Pecot-Dechavassine, 1970; Heuser et al., 1979), and thus, the density of presynaptic active zones is closely related to the efficiency of synaptic transmission (Propst and Ko, 1987). Therefore, the number, size, and distribution of active zones have a profound effect on how information is processed in a neuronal circuit and how the circuit adapts in response to various internal or external cues. In spite of the central role of active zones in synaptic transmission, it is still largely unknown how the number and density of the active zones within a presynaptic terminal are regulated during the development and maturation of synapses or during changes related to synaptic plasticity. The goal of this review is to highlight recent insights into the organization of active zone density and number within a single synaptic terminal or a synaptic bouton and the molecular mechanisms that control the density of active zones during development and synaptic plasticity. The emerging hypothesis from these data is that the active zone density is maintained during the developmental growth of synapses in the central and peripheral nervous systems by molecular mechanisms that do not require neuronal activity. However, active zone density does change in the plastic synapses of the central nervous system (CNS) during stimulus-dependent changes in synaptic efficacy. The analysis of the active zone density within an axon making en passant synapses in C. elegans has revealed important molecular mechanisms for active zone formation, which have been reviewed in detail elsewhere (Jin, 2005).

\section{THE DEFINITION OF ACTIVE ZONES DETECTED WITH DIFFERENT ANALYSIS METHODS}

Active zones have been analyzed using several different techniques, each of which yields a slightly different appearance. We will first review these detection methods and the definition of active zones based on each method. Transmission electron microscopy was first used to describe the active zones in frog neuromuscular junctions (NMJs) as thickened presynaptic membranes containing electron dense material that align with the postsynaptic junctional folds and fuse with synaptic vesicles (Couteaux and Pecot-Dechavassine, 1970). The active zones possess triangular 
electron dense projections that extend from the presynaptic membrane into the cytosol in transmission electron micrographs of frogs and rodents (Couteaux and Pecot-Dechavassine, 1970; Hirokawa and Heuser, 1982; Nishimune et al., 2004; Rowley et al., 2007). The three-dimensional reconstruction of serially sectioned transmission electron micrographs shows the discrete locations of active zones scattered in the presynaptic terminal of rat NMJs (Rowley et al., 2007). At Drosophila NMJs, active zones detected by transmission electron micrographs show an electron dense thickening of the presynaptic membrane with electron dense projections called T-bars that extend from the presynaptic membrane into the cytosol (Zhai and Bellen, 2004). In some Drosophila analyses, active zones are referred to as the synapses, and the T-bars are referred to as the dense bodies. These ultrastructural analyses using transmission electron microscopy provided the basic definition of active zones.

Freeze-fracture electron microscopy revealed a higher resolution structure of the active zones from the interior of the cytosolic half of a plasma membrane (P-face). The NMJs exhibit parallel rows of large intramembranous particles on the P-face of presynaptic membranes in humans, mice, rats, and lizards (Ellisman et al., 1976; Fukunaga et al., 1982; Walrond and Reese, 1985; Fukuoka et al., 1987). Using this methodology, an active zone has been defined as a parallel array of $10-12 \mathrm{~nm}$ intramembranous particles arranged in four rows, with each active zone containing 20 of these intramembranous particles (Ellisman et al., 1976). However, the organization of these large intramembranous particles is different in frog NMJs compared to mammals. Freeze-fracture electron microscopy allowed for the detection of long parallel rows of large intramembranous particles on the P-face and exocytosis events adjacent to these particles in the frog NMJs (Heuser et al., 1974, 1979). A continuum of these intramembranous particles that nearly spans the width of the nerve branch is considered as one active zone in the frog $\mathrm{NMJ}(\mathrm{Ko}, 1985)$. The size of the active zones correlates well with the quantal content at the frog NMJ (Propst and Ko, 1987). The active zones defined by these intramembranous particles are consistent with the active zones defined using transmission electron microscopy, and these findings are further supported by the tomography method.

Electron microscope tomography analysis revealed the presynaptic structures in frog NMJs (Harlow et al., 2001) and mouse NMJs (Nagwaney et al., 2009) in great detail. Macromolecules of active zone materials connect to each other, to the transmembrane peg-like structure (similar to the intramembranous particles detected by freeze-fracture electron microscopy), and to the docked synaptic vesicles at the active zones in the nerve terminals. These electron microscope tomography analyses suggested that the electron dense materials at the active zones detected by transmission electron microscopy and the intramembranous particles detected by the freeze-fracture electron microscopy are part of a large presynaptic protein complex at the active zones.

The ultrastructural analysis methods described above defined the active zone and revealed the high-resolution structure of the active zones. However, an analysis of the distribution pattern of all the active zones within one presynaptic terminal is difficult to obtain with the freeze-fracture and tomography methods and very laborious using the reconstruction of serially sectioned transmission electron micrographs. Needless to say, it becomes a challenge to analyze these parameters over a large number of presynaptic terminals or to analyze the protein composition of the active zones. The recent use of the presynaptic cytosolic protein Bassoon as a marker for active zones has allowed for the detection of active zones using fluorescent immunohistochemistry in the synapses of the central and peripheral nervous system (Nishimune et al., 2004; Dondzillo et al., 2010; Bednarek and Caroni, 2011; Chen et al., 2011a). Bassoon is a large cytosolic scaffolding protein, and its specific localization at the active zones of ribbon synapses and brain synapses was confirmed by immunoelectron microscopy (tom Dieck et al., 1998, 2005; Brandstatter et al., 1999; Richter et al., 1999; Zhang et al., 2000). Bassoon immunohistochemistry reveals a discrete and small punctate staining pattern in the presynaptic terminals, and these puncta are recognized as individual active zones. The definition of the active zones based on fluorescent immunohistochemistry is supported by the immunoelectron microscopy analysis described above and the similarities in the number and distribution pattern of the puncta detected by fluorescent immunohistochemistry and the active zones detected by electron microscopy in NMJs, the calyx of Held, and the ribbon synapses of photoreceptors (Table 1; Satzler et al., 2002; tom Dieck et al., 2005; Rowley et al., 2007; Dondzillo et al., 2010; Chen et al., 2011b). For example, the density of NMJ active zones detected by Bassoon immunohistochemistry is consistent with the active zone density detected by freeze-fracture electron microscopy (Table 1). Furthermore, the total number of puncta detected by immunohistochemistry against active zone proteins Bassoon and Piccolo in the rat calyx of Held is in accordance with the total number of active zones detected by the threedimensional reconstruction of transmission electron micrographs (Table 1; Dondzillo et al., 2010). However, this analysis revealed that the active zones in the calyx of Held have different protein compositions, as shown by some non-overlapping puncta of Bassoon and Piccolo, and suggested that the active zones detected by immunohistochemistry methods must be carefully evaluated depending on the type of synapses to be analyzed. In spite of this, the immunohistochemistry-based active zone analysis is advantageous over electron microscopy in two ways: the ease of analyzing a large sample size and the protein composition of the active zones.

\section{CONSTANT ACTIVE ZONE DENSITY AT THE NMJ}

Active zone density is maintained at a constant level during development at the large synapses of the peripheral nervous system in mammals. Freeze-fracture electron microscopy has revealed that the active zone density is $2.4-2.7$ active zones $/ \mu \mathrm{m}^{2}$ in mouse and human adult NMJs (Fukunaga et al., 1982, 1983; Fukuoka et al., 1987). The Bassoon immunohistochemistry allowed us to analyze the active zones within each presynaptic terminal over large numbers of mouse NMJs (Nishimune et al., 2004; Chen et al., 2011a). While the synapse size and the number of active zones in mouse NMJs increases by more than threefold during postnatal development between postnatal day 0 and 54, the density of the active zones remains constant at 2.3 active zones $/ \mu \mathrm{m}^{2}$ (Chen et al., 2011b). Importantly, the active zone densities measured using two different techniques and in two species make a 


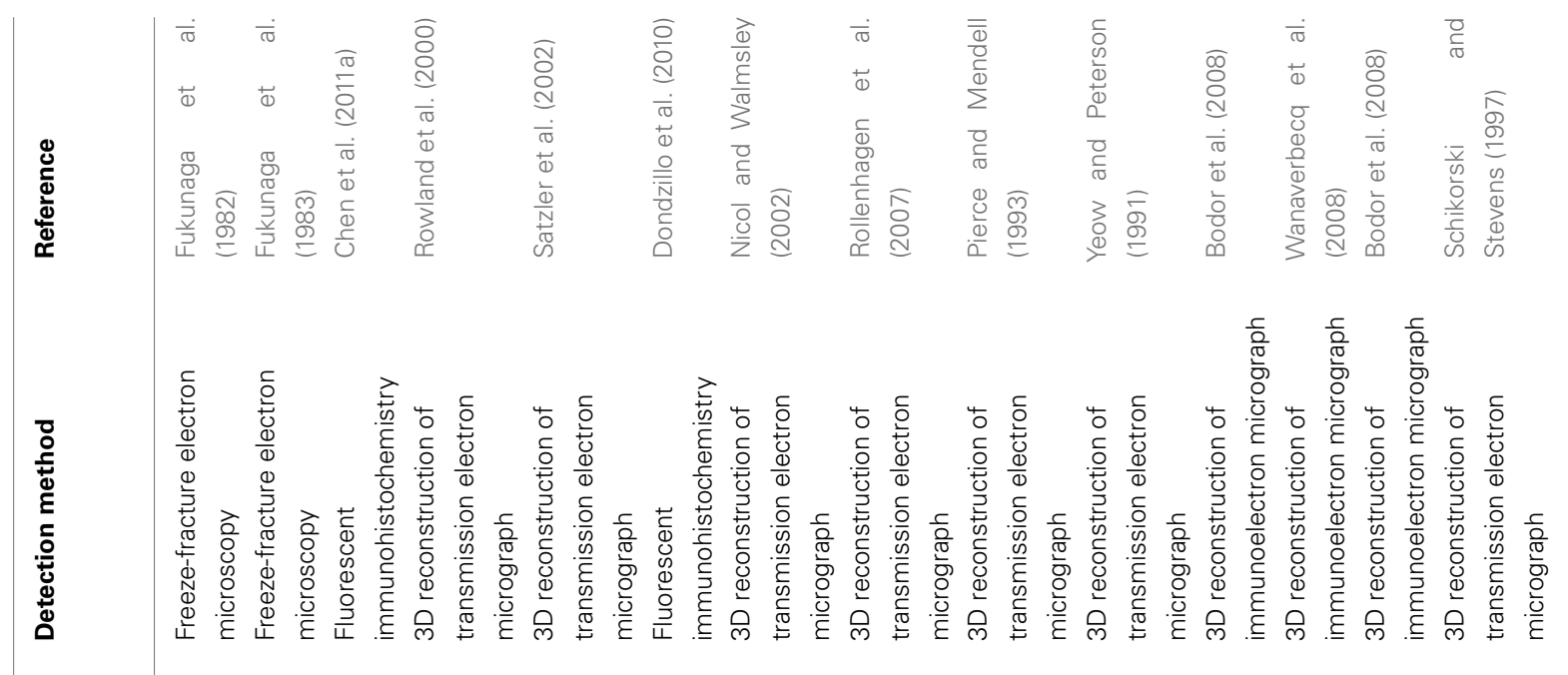

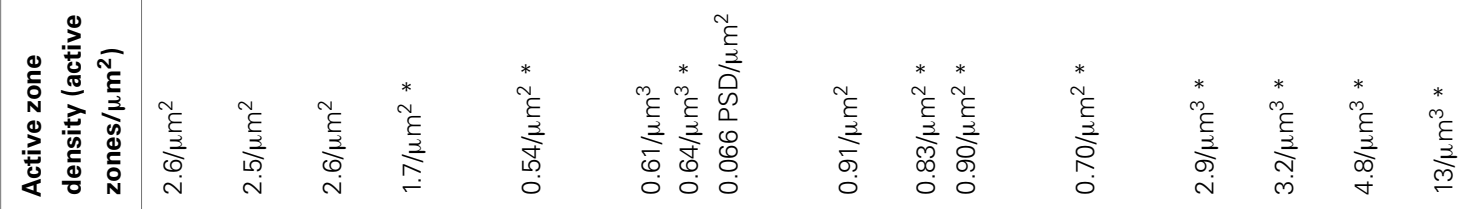

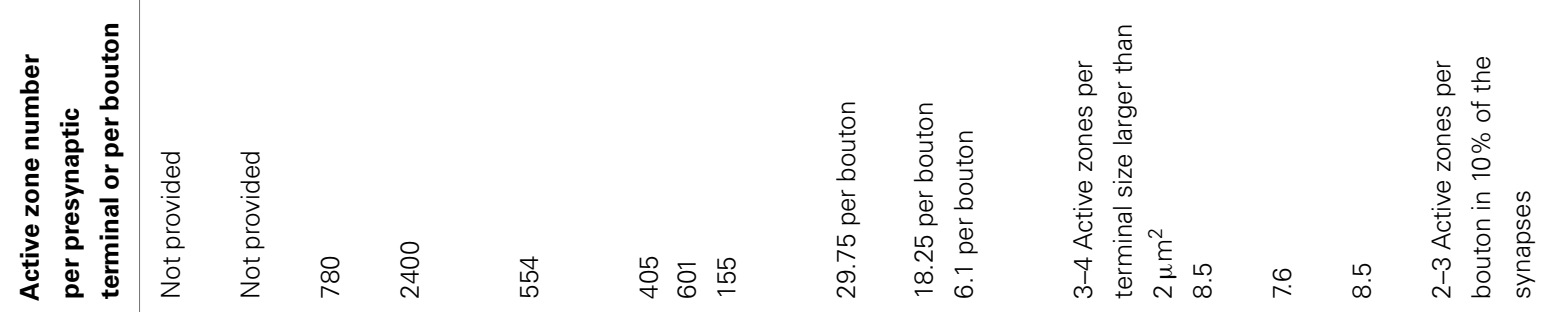

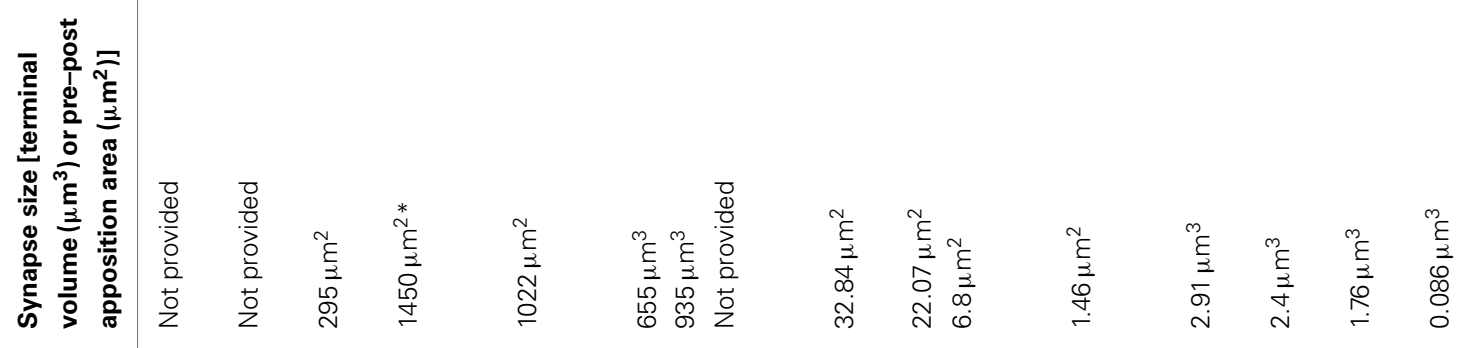

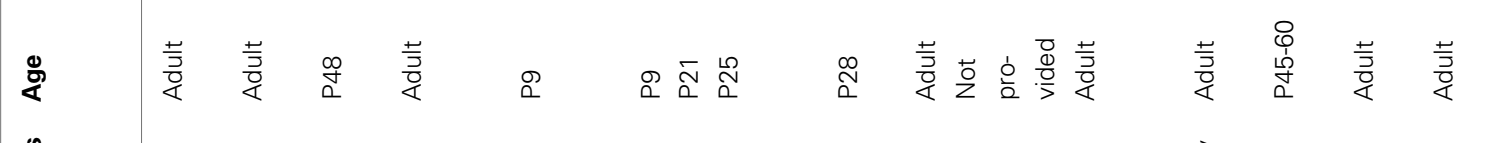

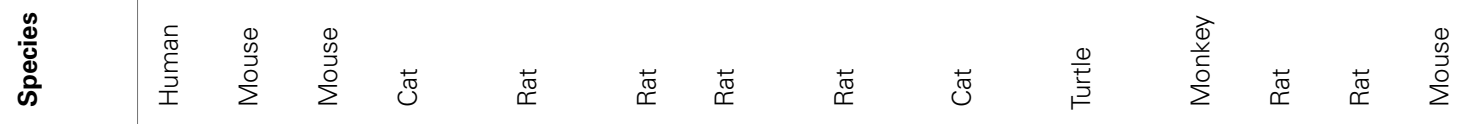

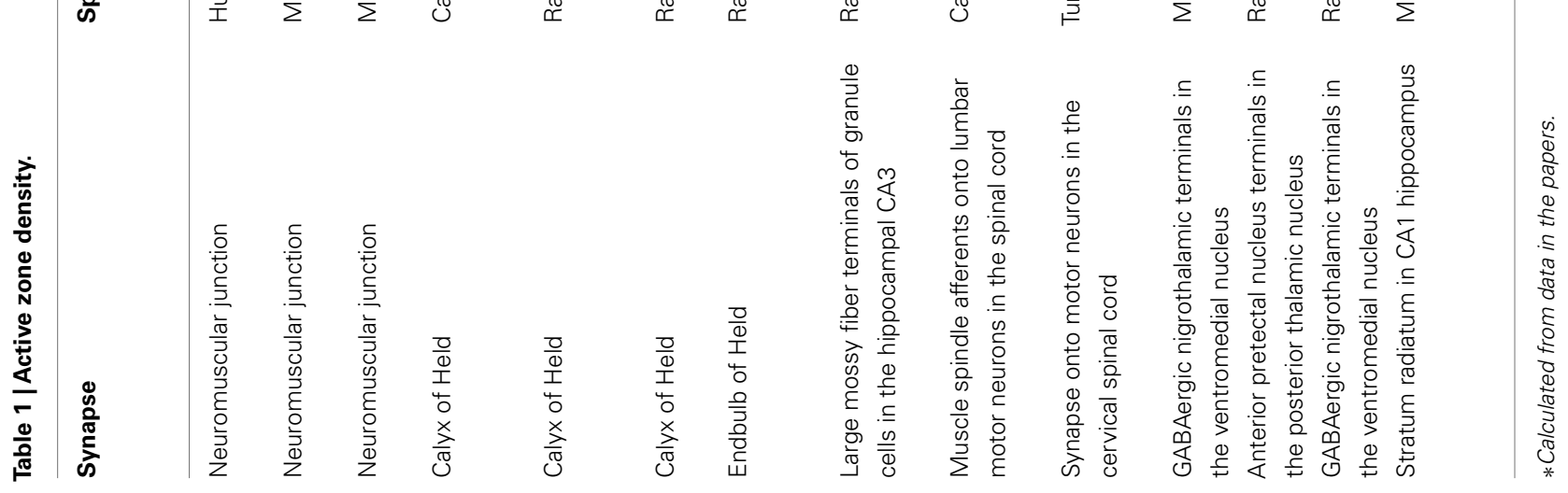


compelling argument that the active zones of mammalian NMJs are maintained at 2.3-2.7 active zones $/ \mu \mathrm{m}^{2}$.

The developmental analysis of active zone formation has also been reported for the frog NMJ using freeze-fracture electron microscopy (Ko, 1985). In spite of the structural differences in these active zones compared to mammals, the number of elongated active zones per postsynaptic junctional fold remains relatively constant at approximately 1.5 active zones per junctional fold throughout development until adulthood (Ko, 1985).

The maintenance of a constant active zone density at synapses as they increase in size is potentially advantageous for synaptic transmission. In the presynaptic terminal, a regulated distance between active zones ensures their access to synaptic vesicles and $\mathrm{Ca}^{2+}$ buffering systems (Llinas et al., 1992; Neher, 1998). In the synaptic cleft, the local concentration of the neurotransmitter will be kept under a certain level by the constant density of active zones, which aids the effective clearance of neurotransmitters (Massoulie and Bon, 1982). On the postsynaptic side, the density of neurotransmitter receptors can be maintained at a constant level during developmental increases in the synapse size, for example, to secure the safety factor of neurotransmission at NMJs (Kelly, 1978). These advantages support the significance of maintaining the active zone density for the efficacy of synaptic transmission.

\section{SYNAPTIC ACTIVITY AND ACTIVE ZONE DENSITY AT THE NMJ}

Does synaptic activity modify the active zone density at NMJs? During development, muscle fibers acquire slow or fast fiber type characteristics (Narusawa et al., 1987; Condon et al., 1990). The NMJs of these two fiber types differ in morphology and size, and the fast fiber type tends to have a larger NMJ (Prakash et al., 1996; Chakkalakal et al., 2010). Motor neurons innervating these fiber types can be classified into subtypes based on the contractile properties of the motor units (Burke et al., 1973; Kanning et al., 2010). These fast and slow motor neurons have different firing rates and durations of post-spike hyperpolarization (Gardiner, 1993; Lee and Heckman, 1998a,b). In spite of these activity differences, the active zone density analyzed by the three-dimensional reconstruction of transmission electron micrographs is similar between the NMJs of fast and slow muscle fiber types (Rowley et al., 2007).

An extreme case of synaptic activity difference can be observed in mice lacking the neurotransmitter acetylcholine. Choline acetyltransferase knockout mice ( $\mathrm{Chat}^{-/}$) cannot synthesize acetylcholine and show no synaptic transmission at NMJs but exhibit a normal number of NMJ active zones when quantified using transmission electron micrographs (Misgeld et al., 2002). This result suggests that the active zone density at embryonic mouse NMJs is independent of the synaptic activity. Just as reduced (or no) synaptic activity has little effect on the number of active zones, enhanced synaptic transmission does not appear to affect active zone formation either. Knockout mice for the collagenous subunit of acetylcholinesterase, ColQ, exhibited no acetylcholinesterase activity at NMJs and showed elongated miniature endplate potential (mEPP) amplitude (Feng et al., 1999). Although the active zone density was not quantified, the knockout mice showed normal active zones with synaptic vesicles in transmission electron micrographs. Similarly, knockout mice for acetylcholinesterase also exhibited ultrastructurally normal NMJs in transmission electron micrographs (Xie et al., 2000). These results suggest that the active zone density at NMJs is independent of the synaptic activity. This contrasts with the role of synaptic activity in synapse elimination and the postsynaptic differentiation of NMJs (Lichtman et al., 1985; Buffelli et al., 2003; Lin et al., 2005; Misgeld et al., 2005).

Analysis using the three-dimensional reconstruction of transmission electron micrographs shows that the active zone density of Drosophila NMJs is also maintained in a homeostatic manner even after manipulations to augment or attenuate synaptic efficiency (Meinertzhagen et al., 1998; Reiff et al., 2002). For example, synaptic transmission at Drosophila larvae NMJs is strengthened by an elevated DGluR-IIA accumulation at NMJs, either by overexpressing DGluR-IIA or by the induction of DGluR-IIA in heterozygotes of the translation-initiation factor poly(A)-binding protein ( $p a b p$; Sigrist et al., 2002). However, the density of the T-bar remains similar to that of the wild-type NMJ level when analyzed by the three-dimensional reconstruction of transmission electron micrographs (Sigrist et al., 2002). This study suggests that the number of T-bars is proportional to the Drosophila NMJ size. Similarly, the puncta size and the distribution pattern of the active zone marker Bruchpilot in NMJs detected by fluorescent immunohistochemistry are indistinguishable between wild-type and mutant Drosophila with increased neuronal activity via the expression of the dominant negative Shaker, with reduced neuronal activity due to decreased sodium channel expression, or with decreased transmitter release in the unc-18 mutant (Graf et al., 2009). In summary, the active zone densities of mouse and Drosophila NMJs are not affected by synaptic activity and are maintained at a constant level.

\section{ACTIVE ZONE DENSITY DURING AGING AND IN DISEASES}

Although the density of active zones is kept constant at NMJs during developmental growth and altered synaptic activity, the active zone is not a stable structure during the normal aging process and some pathological disorders. These conditions cause some active zones to be depleted, which results in a defect in neurotransmission. Aged NMJs demonstrate many morphological alterations, including partial or complete withdrawal of the axons from some postsynaptic sites (Fahim and Robbins, 1982; Banker et al., 1983; Balice-Gordon, 1997; Valdez et al., 2010). However, in fully innervated, aged NMJs, the active zone density detected by Bassoon immunohistochemistry was decreased compared to young adult mice (Chen et al., 2011b). This is consistent with the attenuated mEPP frequency observed at the NMJs of aged mice and rats (Gutmann et al., 1971; Banker et al., 1983; Alshuaib and Fahim, 1991; Fahim, 1997). Thus, active zone density decreases and synaptic transmission weakens at aged NMJs, which may lead to their denervation.

Reduced active zone density at the NMJ was also observed in pathological conditions such as Lambert-Eaton myasthenia syndrome (LEMS) and Pierson's syndrome. LEMS, an autoimmune disease caused by anti-calcium channel autoantibodies, is characterized by a decreased quantal release of acetylcholine from the presynaptic terminal of NMJs (Eaton and Lambert, 1957; Elmqvist and Lambert, 1968; Lambert and Elmqvist, 1971; Kim and Neher, 1988). Freeze-fracture electron microscopy revealed a marked decrease in the active zone density in the NMJs of 
patients with LEMS (Fukunaga et al., 1982). The passive transfer of patient IgG to mice caused LEMS-like electrophysiological changes with reduced active zone numbers at the NMJ as detected by freeze-fracture electron microscopy (Fukunaga et al., 1983; Fukuoka et al., 1987; Nagel et al., 1988). In addition to LEMS, active zone deficiency is also found in another myasthenic disease called Pierson's syndrome. Pierson's syndrome is a newly defined congenital disease caused by mutations in the laminin $\beta 2$ gene (Zenker et al., 2004a,b; Mark et al., 2006). A decreased number of active zones were confirmed by transmission electron microscopy in the muscle biopsies from patients as well as laminin ß2 knockout mice (Noakes et al., 1995; Nishimune et al., 2004; Maselli et al., 2009). Attenuated active zones may partially account for the reduced mEPP frequency and the EPP quantal content in this disease (Maselli et al., 2009). LEMS and Pierson's syndrome may not be the only two neurological diseases that show active zone abnormalities. Gerstmann-Sträussler-Scheinker (GSS) syndrome is one type of fetal prion disease that causes prominent neurodegeneration in the cerebellum and cerebral cortex (Ghetti et al., 1995; Mead, 2006). In a Drosophila model of GSS syndrome, the amount of the active zone protein Bruchpilot was significantly reduced, indicating that an active zone deficiency may be involved in the progress of this disease (Choi et al., 2010). However, it is currently unclear whether patients with GSS syndrome show this active zone deficiency or not. The lack of symptom information may be partially due to the requirement of electron microscopy for active zone detection in the past. The recent discovery of an immunofluorescent labeling of active zone proteins should enable the evaluation of the active zone structure in these neurological diseases in a fast and accurate way (Nishimune et al., 2004; Dondzillo et al., 2010; Bednarek and Caroni, 2011; Chen et al., 2011b). Active zones play an essential role in neurotransmission; thus, a deeper knowledge of active zone changes will definitely enhance the understanding of the pathogenesis of these diseases. Although active zone density has a remarkable ability to remain constant, some factors, such as aging and disease, alter its stability.

\section{ACTIVE ZONE DENSITY IN THE CNS}

Is the active zone density of CNS synapses organized similarly to the NMJ active zones? Partly due to the small size of CNS synapses, many CNS presynaptic terminals possess only one active zone. When analyzed using the three-dimensional reconstruction of transmission electron micrographs, $90 \%$ of the presynaptic boutons exhibit only a single active zone at the synapses within the stratum radiatum in the CA1 region of the mouse hippocampus (Schikorski and Stevens, 1997). Similarly, the active zones on cerebellar climbing fibers and parallel fibers are located in distinct boutons, and each bouton typically has one active zone (defined by the apposing synaptic vesicle cluster and postsynaptic density; Xu-Friedman et al., 2001).

However, many large CNS synapses exhibit multiple active zones per presynaptic terminal in three-dimensional reconstructions of transmission electron micrographs (Table 1). For example, in the auditory brain stem, the calyxes of Held in rats and cats have 405-2400 active zones per nerve terminal (Rowland et al., 2000; Satzler et al., 2002), and the rat endbulb of Held has an average of 155 active zones per endbulb (Nicol and Walmsley, 2002). The large mossy fiber terminals of granule cells in the stratum lucidum of the adult rat hippocampal CA3 region has an average of 18 active zones per bouton (Rollenhagen et al., 2007), and some synapses in the stratum radiatum in the CA1 region of the adult mouse hippocampus have two to three active zones per bouton (Schikorski and Stevens, 1997). Rat and monkey GABAergic nigrothalamic terminals in the ventromedial nucleus have an average of 8.5 active zones per large dendrite (Bodor et al., 2008). In the posterior thalamic nucleus of rats, the nucleus reticularis thalami terminals have an average of two active zones per terminal, while inputs from the anterior pretectal nucleus have an average of 7.6 active zones (Wanaverbecq et al., 2008). Large presynaptic terminals synapsing onto motor neurons in the spinal cord of cats and turtles (Yeow and Peterson, 1991; Pierce and Mendell, 1993) and some parallel fiber synapses onto cerebellar Purkinje cells in young rats (XuFriedman et al., 2001) have more than one active zone per bouton. These variations in active zone number suggest a mechanism for accommodating the active zone number to the synapse size.

Indeed, the maintenance of active zone density can be observed during the development of the calyx of Held in the auditory brainstem, which is one of the largest synapse in the CNS. Between postnatal day 9 and 21, the size of the rat calyx of Held increases 1.4-fold; however, the density of the active zones remains constant at approximately 0.6 active zones per unit calyx size $\left(\mu \mathrm{m}^{3}\right)$ when analyzed by fluorescent immunohistochemistry using Bassoon and Piccolo antibodies (Dondzillo et al., 2010). These results suggest that the active zone density is maintained during the development of this CNS synapse, similar to the NMJs.

The control of active zone density can also be observed in the spinal cord. Synapses on the motor neuron cell body in the spinal cord were analyzed in detail using the three-dimensional reconstruction of transmission electron micrographs (Yeow and Peterson, 1991; Pierce and Mendell, 1993). These analyses revealed a few interesting characteristics of CNS active zones. First, the size of individual active zones rarely exceeded $0.4 \mu \mathrm{m}^{2}$, suggesting that active zones have a limited size for proper function. Second, synapses with larger apposition areas of presynaptic and postsynaptic membranes have two or more discrete regions of active zones within a single synapse, demonstrating a correlation between the active zone number and bouton size (Yeow and Peterson, 1991). Consistently, the total area of the active zones within a single presynaptic terminal is correlated with the bouton volume in a linear fashion (Yeow and Peterson, 1991; Pierce and Mendell, 1993). These observations suggest that the active zone density of this CNS synapse is also controlled.

Hippocampal synapses also show some control of active zone density. At the synapses within the stratum radiatum in the CA1 region of the mouse hippocampus, $8 \%$ have two active zones, and $2 \%$ have three active zones based on the three-dimensional reconstruction of serial transmission electron micrographs (Schikorski and Stevens, 1997). These multiple active zones within a single presynaptic bouton contact different postsynaptic spines. The size of the active zones is matched closely by the postsynaptic density area. Importantly, the active zone area size, which averages $0.039 \mu \mathrm{m}^{2}$ in the hippocampal CA1 region, was linearly related to 
the volume of the presynaptic bouton, suggesting a regulation of active zone density at these hippocampal synapses.

However, while the CNS synapses show controlled active zone density, some hippocampal synapses also show changes in active zone density. The active zones in the hippocampal mossy fiber boutons of adult rats possess on average 18 active zones when analyzed using the three-dimensional reconstruction of transmission electron micrographs (Rollenhagen et al., 2007). These active zones maintained approximately $10 \%$ of the pre- and postsynaptic apposition area during development from postnatal day 28 to $3-$ 4 months of age, suggesting that there is also some control of active zone density in this synapse (Rollenhagen et al., 2007). The detection of multiple active zones within a large mossy fiber terminal in the stratum lucidum of the hippocampal CA3 region is also supported by Bassoon immunohistochemical analysis (Bednarek and Caroni, 2011). The density of these active zones was studied in mice housed in an enriched environment, which is known to enhance learning and memory (Nithianantharajah and Hannan, 2006). Thus, changes in synaptic transmission efficiency are expected in the hippocampus. Consistent with this hypothesis, mice housed in an enriched environment for 2 weeks showed increased morphological complexity of the large mossy fiber terminals. Interestingly, the active zone density remained constant during this period. These observations suggest that active zone density is maintained to some degree even in the hippocampal synapses showing plasticity. However, housing mice in the enriched environment for 4 weeks did increase the density of active zones in the large mossy fiber terminals, suggesting a further modification of presynaptic function (Bednarek and Caroni, 2011). In summary, the examples shown in this section suggest that the density of active zones is controlled in CNS synapses of various sizes, but in contrast to NMJs, some of these synapses show plasticity in the density of active zones.

\section{MOLECULAR CONSTITUENTS OF ACTIVE ZONES AND MECHANISMS OF ACTIVE ZONE FORMATION}

Recently, the molecular identities of active zone-specific proteins and the protein interactions essential for the formation of active zones have been increasingly revealed. The constituents of active zones in vertebrate synapses are called the cytoskeletal matrix of the active zone (Dresbach et al., 2001) and includes Bassoon (tom Dieck et al., 1998), CAST/ELKS/Erc family proteins (Ohtsuka et al., 2002; Wang et al., 2002; Deguchi-Tawarada et al., 2004), Munc13 (Brose et al., 1995; Betz et al., 1998), Piccolo (Cases-Langhoff et al., 1996), and RIM1/2 (Wang et al., 1997). Drosophila active zones contain a member of the ELKS/Rab6IP2/CAST/Erc family of proteins called Bruchpilot (Kittel et al., 2006; Wagh et al., 2006), and C. elegans active zones contain SYD-2 (Yeh et al., 2009). Active zone proteins form a large protein complex by binding to each other (Wang et al., 2002, 2009a; Deguchi-Tawarada et al., 2004; TakaoRikitsu et al., 2004; Dulubova et al., 2005; Ohara-Imaizumi et al., 2005). In addition, these proteins are tethered to the membrane by binding to presynaptic voltage-dependent calcium channels (VDCCs) on the cytosolic side (Coppola et al., 2001; Shibasaki et al., 2004; Kiyonaka et al., 2007; Fouquet et al., 2009; Uriu et al., 2010; Chen et al., 2011a; Kaeser et al., 2011; Billings et al., 2012). Some of these protein complexes are anchored to the presynaptic membrane by the extracellular interactions between VDCCs and synapse organizers (Nishimune et al., 2004; Chen et al., 2011a).

Interestingly, an analysis of knockout mice lacking active zonespecific proteins revealed mostly a reduction in the number of docked synaptic vesicles, but no change in the number of active zones. For example, Rim $1 / 2$ knockout mice show a decrease in the number of docked synaptic vesicles and the density of presynaptic VDCCs in the calyx of Held, but the size of the active zones (defined by the postsynaptic density size) was not altered in the three-dimensional reconstruction of transmission electron micrographs (Han et al., 2011). Similarly, the roles of Bassoon and Piccolo in synaptic vesicle clustering at the active zones were demonstrated in the analyses of the CNS and sensory synapses in the single knockout mice for Bassoon or Piccolo as well as the double mutant mice with a Piccolo knockout combined with a Bassoon knockdown (Altrock et al., 2003; Dick et al., 2003; Specht et al., 2007; Angenstein et al., 2008; Buran et al., 2010; Goetze et al., 2010; Hallermann et al., 2010; Lanore et al., 2010; Mukherjee et al., 2010). However, ELKS2a/CAST knockout mice exhibit a normal number of docked synaptic vesicles and synapse ultrastructural morphology in the hippocampal CA1 region analyzed by transmission electron microscopy (Kaeser et al., 2009). Interestingly, the ELKS2a/CAST deletion causes an increase in inhibitory neurotransmitter release and exploratory behaviors, suggesting some alteration of active zones. Meanwhile, in the Drosophila Bruchpilot mutant, the electron dense projection at the active zone (T-bar) is completely missing in NMJs analyzed by transmission electron microscopy (Kittel et al., 2006; Fouquet et al., 2009). Furthermore, in the Bruchpilot mutant, the density of presynaptic VDCCs is normal at the nascent synapse (active zone) but lower in the more mature synapse (active zone). The Bruchpilot mutant may have a normal density of active zones (defined by the thick presynaptic membrane in transmission electron micrographs), but normal active zones with VDCCs and T-bars are less numerous than in controls when the NMJs mature without Bruchpilot. These defects cause a reduction in the evoked excitatory junctional current amplitudes and quantal content (Kittel et al., 2006).

Although the regulatory mechanism for active zone density is largely unknown, the molecular mechanisms leading to active zone formation have been extensively studied and are reviewed in detail elsewhere (Broadie and Richmond, 2002; Rosenmund et al., 2003; Jin, 2005; Prescott and Zenisek, 2005; Fejtova and Gundelfinger, 2006; Collins and DiAntonio, 2007; Stryker and Johnson, 2007; Jin and Garner, 2008; Owald and Sigrist, 2009; Sigrist and Schmitz, 2010; Wichmann and Sigrist, 2010; Nishimune, 2011a,b).

\section{MOLECULAR MECHANISMS FOR CONTROLLING ACTIVE ZONE DENSITY}

In contrast to the increasing knowledge of active zone formation, less is known about the molecular mechanism that controls the density of active zones. One potential mechanism for controlling active zone density is the role of synapse organizers expressed by the postsynaptic cell. At vertebrate NMJs, the muscle-derived synapse-organizer laminin $\beta 2$ and presynaptic $\mathrm{P} / \mathrm{Q}$-type VDCCs bind extracellularly and organize the active zones (Nishimune et al., 2004). On the cytosolic side of the presynaptic P/Q-type VDCCs, the VDCC $\beta$ subunits bind to Bassoon 
and CAST, demonstrating a mechanism that links an extracellular synapse organizer to the active zone proteins through VDCC subunit complexes (Chen et al., 2011a). The active zone density and the docked synaptic vesicle number are significantly decreased at the NMJs of laminin $\beta 2$ knockout mice, P/Q-type or N-type VDCC ( $\alpha$ subunit) knockout mice, and P/Q- and N-type VDCC double knockout mice when analyzed by transmission electron microscopy or Bassoon immunohistochemistry (Noakes et al., 1995; Nishimune et al., 2004; Chen et al., 2011a). The laminin $\beta 2$ subunit forms a multimeric complex with the laminin $\alpha 4$ subunit, which is also concentrated specifically at the NMJs (Patton, 2000). The concentration of laminin $\alpha 4$ in the synaptic cleft is lower near the active zones and higher between the active zones (Patton et al., 2001). Importantly, laminin $\alpha 4$ knockout mice exhibit mislocalization of the active zones at NMJs without a change in the total number of active zones in transmission electron micrographs (Patton et al., 2001). These results suggest that laminin $\alpha 4$ controls the location of active zones and laminin $\beta 2$ controls the density of active zones in mouse NMJs.

Another synapse organizer at the NMJs that potentially determines active zone density is amyloid precursor protein (APP). APP is involved in the pathogenesis of Alzheimer's disease but has also been shown to accumulate at the NMJs (Schubert et al., 1991; Akaaboune et al., 2000). Double knockout mice for APP and its homolog, APP-like protein 2, exhibit decreased active zone density and synaptic vesicle density but a normal number of docked synaptic vesicles in NMJ profiles of transmission electron micrographs (Wang et al., 2005). Consistent with these defects, mEPP frequency was decreased in the double knockout mice. The conditional deletion in muscle suggests a postsynaptic requirement of APP and/or APP-like protein 2 for the presynaptic differentiation of NMJs (Wang et al., 2009b). These results demonstrate the synaptogenic or synapse maintenance role of APP at the NMJ (Wang et al., 2009b), but the decreased density of active zones in the double knockout mice for APP and APP-like protein 2 awaits further study to distinguish between a primary and secondary phenotype because this mutant shows widespread defects of presynaptic differentiation.

In addition to the extracellular synapse organizers, cytosolic synaptic proteins also have roles in controlling active zone density. In Drosophila, the number and spacing of NMJ active zones are controlled by the inositol phosphatase synaptojanin, skeleton $\beta$-spectrin, the GTPase Rab3, and the threonine kinase Unc-51 (Dickman et al., 2006; Pielage et al., 2006; Graf et al., 2009; Wairkar et al., 2009). Synaptojanin functions at endocytic sites to promote synaptic vesicle uncoating (Verstreken et al., 2003). Drosophila NMJs of synaptojanin mutants show an increased density of active zones in exchange for the decreased size of each active zone, which was revealed by the three-dimensional reconstruction of transmission electron micrographs (Dickman et al., 2006). In wild-type NMJs, most active zones have one dense body (T-bar), but there was more than one dense body per active zone in the synaptojanin mutants, sometimes as many as three. This study suggests that the endocytosis mechanism plays a role in defining the density of active zones. In vertebrates, synaptojanin knockout mice have been generated, but the phenotype of the active zones remains unknown in these mutants (Cremona et al., 1999; Kim et al., 2002).
Cytosolic signaling mechanisms for controlling active zone density are starting to emerge. In the Drosophila mutant of the serine threonine kinase Unc-51, the density of active zones or Tbars is significantly reduced in transmission electron micrographs (Wairkar et al., 2009). Consistent with the reduced active zone density, the extrajunctional potential and quantal content are reduced in this mutant. Unc-51 inhibits the activity of the MAP kinase ERK in vivo and thus, the increased ERK activity in the unc-51 mutant is thought to cause the absence of the active zone protein Bruchpilot at NMJs. Consistent with this hypothesis, an ERK hypomorph can rescue the reduced active zone density, but not the synapse size, in the unc-51 mutant (Wairkar et al., 2009). These results suggest that the Unc-51-ERK signaling pathway negatively controls active zone density and that the reduction of active zone density is not caused by the small synapse phenotype in the unc-51 mutant.

Small GTPases seem to control the number of active zones and the protein composition of active zones in Drosophila NMJs. In the Drosophila GTPase Rab3 loss-of-function mutant, the NMJs have many postsynaptic glutamate receptors without any colocalization of the presynaptic active zone protein Bruchpilot (Graf et al., 2009). A transmission electron microscopy analysis revealed that the density of the active zones with T-bars also decreases in this rab3 mutant, whereas the number of active zones with multiple T-Bars increases, suggesting a redistribution of the active zone components. Interestingly, this phenotype can be rescued by transgenically expressing rab3 for $24 \mathrm{~h}$, suggesting that $r a b 3$ can dynamically regulate the density of active zone components in Drosophila NMJs (Graf et al., 2009). However, rab3abcd quadruple knockout mice did not exhibit an active zone phenotype in transmission electron micrographs (Schluter et al., 2004), suggesting that the intracellular mechanism controlling active zone density is different between Drosophila and mice. A quantitative ultrastructure analysis of the rab3abcd quadruple knockout synapse is needed to confirm this hypothesis.

Similar to Drosophila NMJs, rapid modification of the NMJ active zones also take place in mouse NMJs. Their density decreases by acutely inhibiting the signaling between laminin $\beta 2$ and P/Qtype VDCCs for $48 \mathrm{~h}$ in vivo when analyzed by transmission electron microscopy (Nishimune et al., 2004). Similarly, at the frog NMJ active zones, the parallel rows of intramembranous particles become distorted by transiently reducing the extracellular calcium concentration for $3 \mathrm{~h}$, which was revealed by freeze-fracture electron microscopy (Meriney et al., 1996). These analyses in three species suggest that NMJ active zones are not a rigid structure and can be reorganized within few days.

The cytoskeletal network also plays a role in controlling the active zone density. In Drosophila NMJs, the RNAi-mediated elimination of $\beta$-spectrin in postsynaptic muscles increases the size of presynaptic active zone as analyzed by transmission electron microscopy and the number of presynaptic Bruchpilot puncta per postsynaptic GluR cluster as analyzed by fluorescent immunohistochemistry (Pielage et al., 2006). The distribution pattern and the density of Bruchpilot in the presynaptic terminal were also altered by the reduction of postsynaptic $\beta$-spectrin, suggesting that a retrograde signal from the muscles to the motor nerve terminals controls the active zone density. It is currently unknown whether the molecular mechanism that controls the active zone density 
at the NMJs also functions in CNS synapses. In the rodent CNS, the active zones are supported by a structure called the presynaptic web, which includes spectrins (Phillips et al., 2001). This structure was identified from the electron microscopic observation of the purified synaptic membranes in the synaptosomal fraction. The $\beta$ III spectrin knockout mice showed impaired synaptogenesis in the cerebellum with ataxic and seizure phenotypes, but the NMJ phenotype remains unknown (Stankewich et al., 2010). As previously mentioned in this review, the formation of new synapses and the increase in active zone density are dependent on $\beta$-adducin, a spectrin interacting molecule, in the mouse hippocampus (Bednarek and Caroni, 2011). Taken together, the spectrin skeleton is likely to play a role in defining the density of active zones in vertebrate CNS synapses and NMJs.

\section{PERSPECTIVE}

In this review, we focused on the morphological analyses of active zone density and the molecular mechanisms that control active zone density. Interestingly, the transmitter release properties of active zones within a single presynaptic terminal are not equal. For example, the active zones within one presynaptic terminal of an NMJ have independent release probabilities, which can be deduced by the heterogeneity of the synaptic vesicle released from different active zones (Bennett and Lavidis, 1989; Wyatt and Balice-Gordon, 2008; Luo et al., 2011; Peled and Isacoff, 2011). This heterogeneity of active zone function has been studied in frog, mouse, and Drosophila NMJs, suggesting that it is a common phenomenon across species. Similarly, the variability of neurotransmitter release probability within one axon has been studied at CNS synapses and has been reviewed elsewhere (Pelkey and McBain, 2007; Branco and Staras, 2009). However, the molecular mechanism behind these independent controls of release probability within one presynaptic terminal is not fully understood. How do the mechanism regulating the active zone density and the mechanism controlling the independent release probability cooperate within one presynaptic terminal? Do the

\section{REFERENCES}

Akaaboune, M., Allinquant, B., Farza, H., Roy, K., Magoul, R., Fiszman, M., Festoff, B. W., and Hantai, D. (2000). Developmental regulation of amyloid precursor protein at the neuromuscular junction in mouse skeletal muscle. Mol. Cell. Neurosci. 15, 355-367.

Alshuaib, W. B., and Fahim, M. A. (1991). Depolarization reverses agerelated decrease of spontaneous transmitter release. J. Appl. Physiol. 70, 2066-2071.

Altrock, W. D., Tom Dieck, S., Sokolov, M., Meyer, A. C., Sigler, A., Brakebusch, C., Fassler, R., Richter, K., Boeckers, T. M., Potschka, H., Brandt, C., Loscher, W., Grimberg, D., Dresbach, T., Hempelmann, A., Hassan, H., Balschun, D., Frey, J. U., Brandstatter, J. H., Garner, C. C., Rosenmund, C., and Gundelfinger, E. D. (2003). Functional inactivation

density of active zone and the release probability map change cooperatively or independently beyond the steady level during development, plasticity, aging, and pathological conditions in a given presynaptic terminal? The molecular analysis of active zone density together with the physiological analyses of active zones is needed to elucidate the function of active zones in synaptic transmission.

In summary, the density of active zones affects the efficiency of synaptic transmission and is thus likely to play an essential role in the neural circuit formation. During the formation and maturation of synapses and in some stable mature synapses, the active zone density is likely to be maintained by genetic mechanisms rather than neuronal activity-related mechanisms. However, some CNS synapses can alter the density of active zones beyond this maintenance mechanism. In plastic synapses of the hippocampus, stimulus-dependent changes in synaptic efficacy cause the active zone density to increase. This change in active zone density may contribute to learning and memory. Meanwhile, diseases that result in abnormal active zone density cause severe symptoms in humans. Pearson's syndrome and LEMS cause a decrease in active zone density and lead to profound neuromuscular disorders. In the CNS, single nucleotide polymorphisms in the gene coding the active zone protein Piccolo have been associated with major depressive disorder, suggesting a possible role for active zones in this disease (Sullivan et al., 2008). Thus, the function of the active zones and their regulated density appears to be critical for the proper function of the nervous system. Additional research into active zone density during development, disease, and plasticity is required because the molecular and cellular mechanisms that control the density of presynaptic active zones are just beginning to be elucidated.

\section{ACKNOWLEDGMENTS}

We thank Kausik Si for comments on the manuscript. The work in our laboratory is supported by grants to Hiroshi Nishimune from the Whitehall foundation.

assembly of new synapses and improved memory upon environmental enrichment. Neuron 69, 1132-1146.

Bennett, M. R., and Lavidis, N. A. (1989). The probability of quantal secretion at release sites in different calcium concentrations in toad (Bufo marinus) muscle. J. Physiol. (Lond.) 418, 219-233.

Betz, A., Ashery, U., Rickmann, M., Augustin, I., Neher, E., Südhof, T. C., Rettig, J., and Brose, N. (1998). Munc13-1 is a presynaptic phorbol ester receptor that enhances neurotransmitter release. Neuron 21, 123-136.

Billings, S. E., Clarke, G. L., and Nishimune, H. (2012). ELKS1 and $\mathrm{Ca}^{2+}$ channel subunit beta4 interact and colocalize at cerebellar synapses. Neuroreport 23, 49-54.

Bodor, A. L., Giber, K., Rovo, Z., Ulbert, I., and Acsady, L. (2008). Structura correlates of efficient GABAergic transmission in the basal gangliathalamus pathway. J. Neurosci. 28, 3090-3102.

Branco, T., and Staras, K. (2009). The probability of neurotransmitter release: variability and feedback control at single synapses. Nat. Rev. Neurosci. 10, 373-383.

Brandstatter, J. H., Fletcher, E. L., Garner, C. C., Gundelfinger, E. D., and Wassle, H. (1999). Differential expression of the presynaptic cytomatrix protein bassoon among ribbon synapses in the mammalian retina. Eur. J. Neurosci. 11, 3683-3693.

Broadie, K. S., and Richmond, J. E. (2002). Establishing and sculpting the synapse in Drosophila and C. elegans. Curr. Opin. Neurobiol. 12, 491-498.

Brose, N., Hofmann, K., Hata, Y., and Südhof, T. C. (1995). Mammalian 
homologues of Caenorhabditis elegans unc-13 gene define novel family of C2-domain proteins. J. Biol. Chem. 270, 25273-25280.

Buffelli, M., Burgess, R. W., Feng, G., Lobe, C. G., Lichtman, J. W., and Sanes, J. R. (2003). Genetic evidence that relative synaptic efficacy biases the outcome of synaptic competition. Nature 424, 430-434.

Buran, B. N., Strenzke, N., Neef, A., Gundelfinger, E. D., Moser, T., and Liberman, M. C. (2010). Onset coding is degraded in auditory nerve fibers from mutant mice lacking synaptic ribbons. J. Neurosci. 30, 7587-7597.

Burke, R. E., Levine, D. N., Tsairis, P., and Zajac, F. E. III. (1973). Physiological types and histochemical profiles in motor units of the cat gastrocnemius. J. Physiol. (Lond.) 234, 723-748.

Cases-Langhoff, C., Voss, B., Garner, A. M., Appeltauer, U., Takei, K., Kindler, S., Veh, R. W., De Camilli, P., Gundelfinger, E. D., and Garner, C. C. (1996). Piccolo, a novel 420 kDa protein associated with the presynaptic cytomatrix. Eur. J. Cell Biol. 69, 214-223.

Chakkalakal, J. V., Nishimune, H., Ruas, J. L., Spiegelman, B. M., and Sanes, J. R. (2010). Retrograde influence of muscle fibers on their innervation revealed by a novel marker for slow motoneurons. Development 137, 3489-3499.

Chen, J., Billings, S. E., and Nishimune, H. (2011a). Calcium channels link the muscle-merived synapse organizer laminin beta2 to Bassoon and CAST/Erc2 to organize presynaptic active zones. J. Neurosci. 31, 512-525.

Chen, J., Mizushige, T., and Nishimune, H. (2011b). Active zone density is conserved during synaptic growth but impaired in aged mice. J. Comp. Neurol. 520, 434-452.

Choi, J. K., Jeon, Y. C., Lee, D. W., Oh, J. M., Lee, H. P., Jeong, B. H., Carp, R. I., Koh, Y. H., and Kim, Y. S. (2010). A Drosophila model of GSS syndrome suggests defects in active zones are responsible for pathogenesis of GSS syndrome. Hum. Mol. Genet. 19, 4474-4489.

Collins, C. A., and DiAntonio, A. (2007). Synaptic development: insights from Drosophila. Curr. Opin. Neurobiol. 17, 35-42.

Condon, K., Silberstein, L., Blau, H. M., and Thompson, W. J. (1990). Development of muscle fiber types in the prenatal rat hindlimb. Dev. Biol. 138, 256-274.
Coppola, T., Magnin-Luthi, S., PerretMenoud, V., Gattesco, S., Schiavo, G., and Regazzi, R. (2001). Direct interaction of the Rab3 effector RIM with $\mathrm{Ca}^{2+}$ channels, SNAP-25, and synaptotagmin. J. Biol. Chem. 276, 32756-32762.

Couteaux, R., and Pecot-Dechavassine, M. (1970). Synaptic vesicles and pouches at the level of "active zones" of the neuromuscular junction. C. R. Hebd. Seances Acad. Sci. Ser. D Sci. Nat. 271, 2346-2349.

Cremona, O., Di Paolo, G., Wenk, M. R., Luthi, A., Kim, W. T., Takei, K., Daniell, L., Nemoto, Y., Shears, S. B., Flavell, R. A., Mccormick, D. A., and De Camilli, P. (1999). Essential role of phosphoinositide metabolism in synaptic vesicle recycling. Cell 99, 179-188.

Deguchi-Tawarada, M., Inoue, E., Takao-Rikitsu, E., Inoue, M., Ohtsuka, T., and Takai, Y. (2004). CAST2: identification and characterization of a protein structurally related to the presynaptic cytomatrix protein CAST. Genes Cells 9, 15-23.

Dick, O., Tom Dieck, S., Altrock, W. D., Ammermuller, J., Weiler, R., Garner, C. C., Gundelfinger, E. D., and Brandstatter, J. H. (2003). The presynaptic active zone protein bassoon is essential for photoreceptor ribbon synapse formation in the retina. Neuron 37, 775-786.

Dickman, D. K., Lu, Z., Meinertzhagen, I. A., and Schwarz, T. L. (2006). Altered synaptic development and active zone spacing in endocytosis mutants. Curr. Biol. 16, 591-598.

Dondzillo, A., Sätzler, K., Horstmann, H., Altrock, W. D., Gundelfinger, E. D., and Kuner, T. (2010). Targeted three-dimensional immunohistochemistry reveals localization of presynaptic proteins bassoon and piccolo in the rat calyx of held before and after the onset of hearing. J. Comp. Neurol. 518, 1008-1029.

Dresbach, T., Qualmann, B., Kessels, M. M., Garner, C. C., and Gundelfinger, E. D. (2001). The presynaptic cytomatrix of brain synapses. Cell. Mol. Life Sci. 58, 94-116.

Dulubova, I., Lou, X., Lu, J., Huryeva, I., Alam, A., Schneggenburger, R., Südhof, T. C., and Rizo, J. (2005). A Munc13/RIM/Rab3 tripartite complex: from priming to plasticity? EMBO J. 24, 2839-2850.

Eaton, L. M., and Lambert, E. H. (1957). Electromyography and electric stimulation of nerves in diseases of motor unit; observations on myasthenic syndrome associated with malignant tumors. J. Am. Med. Assoc. 163, 1117-1124.

Ellisman, M. H., Rash, J. E., Staehelin, L. A., and Porter, K. R. (1976). Studies of excitable membranes. II. A comparison of specializations at neuromuscular junctions and nonjunctional sarcolemmas of mammalian fast and slow twitch muscle fibers. $J$. Cell Biol. 68, 752-774.

Elmqvist, D., and Lambert, E. H. (1968) Detailed analysis of neuromuscular transmission in a patient with the myasthenic syndrome sometimes associated with bronchogenic carcinoma. Mayo Clin. Proc. 43, 689-713.

Fahim, M. A. (1997). Endurance exercise modulates neuromuscular junction of $\mathrm{C} 57 \mathrm{BL} / 6 \mathrm{NNia}$ aging mice. $J$. Appl. Physiol. 83, 59-66.

Fahim, M. A., and Robbins, N. (1982). Ultrastructural studies of young and old mouse neuromuscular junctions. J. Neurocytol. 11, 641-656.

Fejtova, A., and Gundelfinger, E. D. (2006). Molecular organization and assembly of the presynaptic active zone of neurotransmitter release. Results Probl. Cell Differ. 43, 49-68.

Feng, G., Krejci, E., Molgo, J., Cunningham, J. M., Massoulie, J., and Sanes, J. R. (1999). Genetic analysis of collagen $\mathrm{Q}$ : roles in acetylcholinesterase and butyrylcholinesterase assembly and in synaptic structure and function. J. Cell Biol. 144, 1349-1360.

Fouquet, W., Owald, D., Wichmann, C. Mertel, S., Depner, H., Dyba, M., Hallermann, S., Kittel, R. J., Eimer, S., and Sigrist, S. J. (2009). Maturation of active zone assembly by Drosophila bruchpilot. J. Cell Biol. 186, 129-145.

Fukunaga, H., Engel, A. G., Lang, B. Newsom-Davis, J., and Vincent, A. (1983). Passive transfer of LambertEaton myasthenic syndrome with IgG from man to mouse depletes the presynaptic membrane active zones. Proc. Natl. Acad. Sci. U.S.A. 80, 7636-7640.

Fukunaga, H., Engel, A. G., Osame, M., and Lambert, E. H. (1982). Paucity and disorganization of presynaptic membrane active zones in the lambert-eaton myasthenic syndrome. Muscle Nerve 5, 686-697.

Fukuoka, T., Engel, A. G., Lang, B., Newsom-Davis, J., Prior, C., and Wray, D. W. (1987). Lambert-Eaton myasthenic syndrome: I. Early morphological effects of IgG on the presynaptic membrane active zones. Ann. Neurol. 22, 193-199.

Gardiner, P. F. (1993). Physiological properties of motoneurons innervating different muscle unit types in rat gastrocnemius. J. Neurophysiol. 69, 1160-1170.

Ghetti, B., Dlouhy, S. R., Giaccone, G., Bugiani, O., Frangione, B., Farlow, M. R., and Tagliavini, F. (1995). Gerstmann-StrausslerScheinker disease and the Indiana kindred. Brain Pathol. 5, 61-75.

Goetze, B., Schmidt, K.-F., Lehmann, K., Altrock, W. D., Gundelfinger, E. D., and Lowel, S. (2010). Vision and visual cortical maps in mice with a photoreceptor synaptopathy: reduced but robust visual capabilities in the absence of synaptic ribbons. Neuroimage 49, 1622-1631.

Graf, E. R., Daniels, R. W., Burgess, R. W., Schwarz, T. L., and Diantonio, A. (2009). Rab3 Dynamically controls protein composition at active zones. Neuron 64, 663-677.

Gutmann, E., Hanzlikova, V., and Vysokocil, F. (1971). Age changes in cross striated muscle of the rat. $J$. Physiol. (Lond.) 216, 331-343.

Hallermann, S., Fejtova, A., Schmidt, H., Weyhersmüller, A., Silver, R. A., Gundelfinger, E. D., and Eilers, J. (2010). Bassoon speeds vesicle reloading at a central excitatory synapse. Neuron 68, 710-723.

Han, Y., Kaeser, P. S., Südhof, T. C., and Schneggenburger, R. (2011). RIM determines $\mathrm{Ca}^{2+}$ channel density and vesicle docking at the presynaptic active zone. Neuron 69, 304-316.

Harlow, M. L., Ress, D., Stoschek, A., Marshall, R. M., and Mcmahan, U. J. (2001). The architecture of active zone material at the frog's neuromuscular junction. Nature 409 , 479-484.

Heuser, J. E., Reese, T. S., Dennis, M. J., Jan, Y., Jan, L., and Evans, L. (1979). Synaptic vesicle exocytosis captured by quick freezing and correlated with quantal transmitter release. J. Cell Biol. 81, 275-300.

Heuser, J. E., Reese, T. S., and Landis, D. M. (1974). Functional changes in frog neuromuscular junctions studied with freeze-fracture. J. Neurocytol. 3, 109-131.

Hirokawa, N., and Heuser, J. E. (1982). Internal and external differentiations of the postsynaptic membrane at the neuromuscular junction. $J$. Neurocytol. 11, 487-510.

Jin, Y. (2005). Synaptogenesis. WormBook 1-11. Available at: http://www.wormbook.org

Jin, Y., and Garner, C. C. (2008). Molecular mechanisms of presynaptic differentiation. Annu. Rev. Cell Dev. Biol. 24, 237-262.

Kaeser, P. S., Deng, L., Chávez, A. E., Liu, X., Castillo, P. E., and Südhof, T. C. (2009). ELKS2alpha/CAST 
deletion selectively increases neurotransmitter release at inhibitory synapses. Neuron 64, 227-239.

Kaeser, P. S., Deng, L., Wang, Y., Dulubova, I., Liu, X., Rizo, J., and Südhof, T. C. (2011). RIM proteins tether $\mathrm{Ca}^{2+}$ channels to presynaptic active zones via a direct PDZ-domain interaction. Cell 144, 282-295.

Kanning, K. C., Kaplan, A., and Henderson, C. E. (2010). Motor neuron diversity in development and disease. Annu. Rev. Neurosci. 33, 409-440.

Kelly, S. S. (1978). The effect of age on neuromuscular transmission. $J$. Physiol. (Lond.) 274, 51-62.

Kim, W. T., Chang, S., Daniell, L., Cremona, O., Di Paolo, G., and De Camilli, P. (2002). Delayed reentry of recycling vesicles into the fusion-competent synaptic vesicle pool in synaptojanin 1 knockout mice. Proc. Natl. Acad. Sci. U.S.A. 99, 17143-17148.

Kim, Y. I., and Neher, E. (1988). IgG from patients with LambertEaton syndrome blocks voltagedependent calcium channels. Science 239, 405-408.

Kittel, R. J., Wichmann, C., Rasse, T. M., Fouquet, W., Schmidt, M., Schmid, A., Wagh, D. A., Pawlu, C., Kellner, R. R., Willig, K. I., Hell, S. W., Buchner, E., Heckmann, M., and Sigrist, S. J. (2006). Bruchpilot promotes active zone assembly, $\mathrm{Ca}^{2+}$ channel clustering, and vesicle release. Science 312, 1051-1054.

Kiyonaka, S., Wakamori, M., Miki, T., Uriu, Y., Nonaka, M., Bito, H., Beedle, A. M., Mori, E., Hara, Y., De Waard, M., Kanagawa, M., Itakura, M., Takahashi, M., Campbell, K. P., and Mori, Y. (2007). RIM1 confers sustained activity and neurotransmitter vesicle anchoring to presynaptic $\mathrm{Ca}^{2+}$ channels. Nat. Neurosci. 10, 691-701.

Ko, C. P. (1985). Formation of the active zone at developing neuromuscular junctions in larval and adult bullfrogs. J. Neurocytol. 14, 487-512.

Lambert, E. H., and Elmqvist, D. (1971). Quantal components of end-plate potentials in the myasthenic syndrome. Ann. N. Y. Acad. Sci. 183, 183-199.

Lanore, F., Blanchet, C., Fejtova, A., Pinheiro, P., Richter, K., Balschun, D., Gundelfinger, E. D., and Mulle, C. (2010). Impaired development of hippocampal mossy fibre synapses in mouse mutants for the presynaptic scaffold protein Bassoon. $J$. Physiol. (Lond.) 588, 2133-2145.
Lee, R. H., and Heckman, C. J. (1998a). Bistability in spinal motoneurons in vivo: systematic variations in rhythmic firing patterns. J. Neurophysiol. 80, 572-582.

Lee, R. H., and Heckman, C. J. (1998b). Bistability in spinal motoneurons in vivo: systematic variations in persistent inward currents. J. Neurophysiol. 80, 583-593.

Lichtman, J. W., Wilkinson, R. S., and Rich, M. M. (1985). Multiple innervation of tonic endplates revealed by activity-dependent uptake of fluorescent probes. Nature 314, 357-359.

Lin, W., Dominguez, B., Yang, J., Aryal, P., Brandon, E. P., Gage, F. H., and Lee, K.-F. (2005). Neurotransmitter acetylcholine negatively regulates neuromuscular synapse formation by a Cdk5-dependent mechanism. Neuron 46, 569-579.

Llinas, R., Sugimori, M., and Silver, R. B. (1992). Microdomains of high calcium concentration in a presynaptic terminal. Science 256, 677-679.

Luo, F., Dittrich, M., Stiles, J. R., and Meriney, S. D. (2011). Single-pixel optical fluctuation analysis of calcium channel function in active zones of motor nerve terminals. $J$. Neurosci. 31, 11268-11281.

Mark, K., Reis, A., and Zenker, M. (2006). Prenatal findings in four consecutive pregnancies with fetal Pierson syndrome, a newly defined congenital nephrosis syndrome. Prenat. Diagn. 26, 262-266.

Maselli, R. A., Ng, J. J., Anderson, J. A., Cagney, O., Arredondo, J., Williams, C., Wessel, H. B., Abdel-Hamid, H., and Wollmann, R. L. (2009). Mutations in LAMB2 causing a severe form of synaptic congenital myasthenic syndrome. J. Med. Genet. 46, 203-208.

Massoulie, J., and Bon, S. (1982). The molecular forms of cholinesterase and acetylcholinesterase in vertebrates. Annu. Rev. Neurosci. 5, $57-106$.

Mead, S. (2006). Prion disease genetics. Eur. J. Hum. Genet. 14, 273-281.

Meinertzhagen, I. A., Govind, C. K., Stewart, B. A., Carter, J. M., and Atwood, H. L. (1998). Regulated spacing of synapses and presynaptic active zones at larval neuromuscular junctions in different genotypes of the flies Drosophila and Sarcophaga. J. Comp. Neurol. 393, 482-492.

Meriney, S. D., Wolowske, B., Ezzati, E., and Grinnell, A. D. (1996). Low calcium-induced disruption of active zone structure and function at the frog neuromuscular junction. Synapse 24, 1-11.
Misgeld, T., Burgess, R. W., Lewis, R. M., Cunningham, J. M., Lichtman, J. W., and Sanes, J. R. (2002). Roles of neurotransmitter in synapse formation: development of neuromuscular junctions lacking choline acetyltransferase. Neuron 36, 635-648.

Misgeld, T., Kummer, T. T., Lichtman, J. W., and Sanes, J. R. (2005). Agrin promotes synaptic differentiation by counteracting an inhibitory effect of neurotransmitter. Proc. Natl. Acad. Sci. U.S.A. 102, 11088-11093.

Mukherjee, K., Yang, X., Gerber, S. H., Kwon, H.-B., Ho, A., Castillo, P. E., Liu, X., and Südhof, T. C. (2010). Piccolo and bassoon maintain synaptic vesicle clustering without directly participating in vesicle exocytosis. Proc. Natl. Acad. Sci. U.S.A. 107, 6504-6509.

Nagel, A., Engel, A. G., Lang, B., Newsom-Davis, J., and Fukuoka, T. (1988). Lambert-Eaton myasthenic syndrome IgG depletes presynaptic membrane active zone particles by antigenic modulation. Ann. Neurol. 24, 552-558.

Nagwaney, S., Harlow, M. L., Jung, J. H., Szule, J. A., Ress, D., Xu, J., Marshall, R. M., and Mcmahan, U. J. (2009). Macromolecular connections of active zone material to docked synaptic vesicles and presynaptic membrane at neuromuscular junctions of mouse. J. Comp. Neurol. $513,457-468$

Narusawa, M., Fitzsimons, R. B., Izumo, S., Nadal-Ginard, B., Rubinstein, N. A., and Kelly, A. M. (1987). Slow myosin in developing rat skeletal muscle. J. Cell Biol. 104, 447-459.

Neher, E. (1998). Vesicle pools and $\mathrm{Ca}^{2+}$ microdomains: new tools for understanding their roles in neurotransmitter release. Neuron 20, 389-399.

Nicol, M. J., and Walmsley, B. (2002). Ultrastructural basis of synaptic transmission between endbulbs of Held and bushy cells in the rat cochlear nucleus. J. Physiol. (Lond.) 539, 713-723.

Nishimune, H. (2011a). Transsynaptic channelosomes: non-conducting roles of ion channels in synapse formation. Channels 5, 432-439.

Nishimune, H. (2011b). Molecular mechanism of active zone organization at vertebrate neuromuscular junctions. Mol. Neurobiol. 45, 1-16.

Nishimune, H., Sanes, J. R., and Carlson, S. S. (2004). A synaptic laminincalcium channel interaction organizes active zones in motor nerve terminals. Nature 432, 580-587.

Nithianantharajah, J., and Hannan, A. J. (2006). Enriched environments, experience-dependent plasticity and disorders of the nervous system. Nat. Rev. Neurosci. 7, 697-709.

Noakes, P. G., Gautam, M., Mudd, J., Sanes, J. R., and Merlie, J. P. (1995). Aberrant differentiation of neuromuscular junctions in mice lacking s-laminin/laminin beta 2 . Nature 374, 258-262.

Ohara-Imaizumi, M., Ohtsuka, T., Matsushima, S., Akimoto, Y., Nishiwaki, C., Nakamichi, Y., Kikuta, T., Nagai, S., Kawakami, H., Watanabe, T., and Nagamatsu, S. (2005). ELKS, a protein structurally related to the active zone-associated protein CAST, is expressed in pancreatic beta cells and functions in insulin exocytosis: interaction of ELKS with exocytotic machinery analyzed by total internal reflection fluorescence microscopy. Mol. Biol. Cell 16, 3289-3300.

Ohtsuka, T., Takao-Rikitsu, E., Inoue, E. Inoue, M., Takeuchi, M., Matsubara, K., Deguchi-Tawarada, M., Satoh, K., Morimoto, K., Nakanishi, H., and Takai, Y. (2002). Cast: a novel protein of the cytomatrix at the active zone of synapses that forms a ternary complex with RIM1 and munc13-1. J. Cell Biol. 158, 577-590.

Owald, D., and Sigrist, S. J. (2009). Assembling the presynaptic active zone. Curr. Opin. Neurobiol. 19, 311-318.

Patton, B. L. (2000). Laminins of the neuromuscular system. Microsc. Res. Tech. 51, 247-261.

Patton, B. L., Cunningham, J. M., Thyboll, J., Kortesmaa, J., Westerblad, H., Edstrom, L., Tryggvason, K., and Sanes, J. R. (2001). Properly formed but improperly localized synaptic specializations in the absence of laminin alpha4. Nat. Neurosci. 4, 597-604.

Peled, E. S., and Isacoff, E. Y. (2011). Optical quantal analysis of synaptic transmission in wild-type and rab3mutant Drosophila motor axons. Nat. Neurosci. 14, 519-526.

Pelkey, K. A., and McBain, C. J. (2007). Differential regulation at functionally divergent release sites along a common axon. Curr. Opin. Neurobiol. 17, 366-373.

Phillips, G. R., Huang, J. K., Wang, Y., Tanaka, H., Shapiro, L., Zhang, W., Shan, W. S., Arndt, K., Frank, M., Gordon, R. E., Gawinowicz, M. A., Zhao, Y., and Colman, D. R. (2001). The presynaptic particle web: ultrastructure, composition, dissolution, and reconstitution Neuron 32, 63-77.

Pielage, J., Fetter, R. D., and Davis, G. W. (2006). A postsynaptic spectrin scaffold defines active zone size, spacing, and efficacy at the Drosophila 
neuromuscular junction. J. Cell Biol. 175, 491-503.

Pierce, J. P., and Mendell, L. M. (1993). Quantitative ultrastructure of Ia boutons in the ventral horn: scaling and positional relationships. $J$. Neurosci. 13, 4748-4763.

Prakash, Y. S., Miller, S. M., Huang, M., and Sieck, G. C. (1996). Morphology of diaphragm neuromuscular junctions on different fibre types. $J$. Neurocytol. 25, 88-100.

Prescott, E. D., and Zenisek, D. (2005). Recent progress towards understanding the synaptic ribbon. Curr. Opin. Neurobiol. 15, 431-436.

Propst, J., and Ko, C. (1987). Correlations between active zone ultrastructure and synaptic function studied with freeze-fracture of physiologically identified neuromuscular junctions. J. Neurosci. 7, 3654-3664.

Reiff, D. F., Thiel, P. R., and Schuster, C. M. (2002). differential regulation of active zone density during long-term strengthening of Drosophila neuromuscular junctions. J. Neurosci. 22, 9399-9409.

Richter, K., Langnaese, K., Kreutz, M. R., Olias, G., Zhai, R., Scheich, H., Garner, C. C., and Gundelfinger, E. D. (1999). Presynaptic cytomatrix protein bassoon is localized at both excitatory and inhibitory synapses of rat brain. J. Comp. Neurol. 408, 437-448.

Rollenhagen, A., Satzler, K., Rodriguez, E. P., Jonas, P., Frotscher, M., and Lubke, J. H. (2007). Structural determinants of transmission at large hippocampal mossy fiber synapses. $J$. Neurosci. 27, 10434-10444.

Rosenmund, C., Rettig, J., and Brose, N. (2003). Molecular mechanisms of active zone function. Curr. Opin. Neurobiol. 13, 509-519.

Rowland, K. C., Irby, N. K., and Spirou, G. A. (2000). Specialized synapse-associated structures within the calyx of Held. J. Neurosci. 20, 9135-9144.

Rowley, K. L., Mantilla, C. B., Ermilov, L. G., and Sieck, G. C. (2007). Synaptic vesicle distribution and release at rat diaphragm neuromuscular junctions. J. Neurophysiol. 98, 478-487.

Satzler, K., Sohl, L. F., Bollmann, J. H., Borst, J. G., Frotscher, M., Sakmann, B., and Lubke, J. H. (2002). Threedimensional reconstruction of a calyx of Held and its postsynaptic principal neuron in the medial nucleus of the trapezoid body. $J$. Neurosci. 22, 10567-10579.

Schikorski, T., and Stevens, C. F. (1997). Quantitative ultrastructural analysis of hippocampal excitatory synapses. J. Neurosci. 17, 5858-5867.

Schluter, O. M., Schmitz, F., Jahn, R., Rosenmund, C., and Südhof, T. C. (2004). A complete genetic analysis of neuronal Rab3 function. J. Neurosci. 24, 6629-6637.

Schubert, W., Prior, R., Weidemann, A., Dircksen, H., Multhaup, G., Masters, C. L., and Beyreuther, K. (1991) Localization of Alzheimer beta A4 amyloid precursor protein at central and peripheral synaptic sites. Brain Res. 563, 184-194.

Shibasaki, T., Sunaga, Y., Fujimoto, K., Kashima, Y., and Seino, S. (2004). Interaction of ATP sensor, cAMP sensor, $\mathrm{Ca}^{2+}$ sensor, and voltagedependent $\mathrm{Ca}^{2+}$ channel in insulin granule exocytosis. J. Biol. Chemis. 279, 7956-7961.

Sigrist, S. J., and Schmitz, D. (2010). Structural and functional plasticity of the cytoplasmic active zone. Curr. Opin. Neurobiol. 21, 1-7.

Sigrist, S. J., Thiel, P. R., Reiff, D. F., and Schuster, C. M. (2002). The postsynaptic glutamate receptor subunit DGluR-IIA mediates long-term plasticity in Drosophila. J. Neurosci. 22, 7362-7372.

Specht, D., Tom Dieck, S., Ammermuller, J., Regus-Leidig, H., Gundelfinger, E. D., and Brandstatter, J. H. (2007). Structural and functional remodeling in the retina of a mouse with a photoreceptor synaptopathy: plasticity in the rod and degeneration in the cone system. Eur. J. Neurosci. 26, 2506-2515.

Stankewich, M. C., Gwynn, B., Ardito, T., Ji, L., Kim, J., Robledo, R. F., Lux, S. E., Peters, L. L., and Morrow, J. S. (2010). Targeted deletion of betaIII spectrin impairs synaptogenesis and generates ataxic and seizure phenotypes. Proc. Natl. Acad. Sci. U.S.A. 107, 6022-6027.

Stryker, E., and Johnson, K. G. (2007). LAR, liprin alpha and the regulation of active zone morphogenesis. J. Cell. Sci. 120, 3723-3728.

Sullivan, P. F., De Geus, E. J. C., Willemsen, G., James, M. R., Smit, J. H., Zandbelt, T., Arolt, V., Baune, B. T., Blackwood, D., Cichon, S., Coventry, W. L., Domschke, K., Farmer, A., Fava, M., Gordon, S. D., He, Q., Heath, A. C., Heutink, P., Holsboer, F., Hoogendijk, W. J., Hottenga, J. J., Hu, Y., Kohli, M., Lin, D., Lucae, S., Macintyre, D. J., Maier, W., Mcghee, K. A., Mcguffin, P., Montgomery, G. W., Muir, W. J., Nolen, W. A., Nothen, M. M., Perlis, R. H., Pirlo, K., Posthuma, D., Rietschel, M., Rizzu, P., Schosser, A., Smit, A. B., Smoller, J. W., Tzeng, J. Y., Van Dyck,
R., Verhage, M., Zitman, F. G., Martin, N. G., Wray, N. R., Boomsma, D. I., and Penninx, B. W. J. H. (2008) Genome-wide association for major depressive disorder: a possible role for the presynaptic protein piccolo. Mol. Psychiatry 14, 359-375.

Takao-Rikitsu, E., Mochida, S., Inoue, E., Deguchi-Tawarada, M., Inoue, M., Ohtsuka, T., and Takai, Y. (2004) Physical and functional interaction of the active zone proteins, CAST, RIM1, and Bassoon, in neurotransmitter release. J. Cell Biol. 164 301-311.

tom Dieck, S., Altrock, W. D., Kessels, M. M., Qualmann, B., Regus, H., Brauner, D., Fejtova, A., Bracko, O., Gundelfinger, E. D., and Brandstatter, J. H. (2005). Molecular dissection of the photoreceptor ribbon synapse: physical interaction of Bassoon and RIBEYE is essential for the assembly of the ribbon complex. $J$. Cell Biol. 168, 825-836.

tom Dieck, S., Sanmarti-Vila, L., Langnaese, K., Richter, K., Kindler, S., Soyke, A., Wex, H., Smalla, K. H., Kampf, U., Franzer, J. T., Stumm, M., Garner, C. C., and Gundelfinger, E. D. (1998). Bassoon, a novel zincfinger CAG/glutamine-repeat protein selectively localized at the active zone of presynaptic nerve terminals. J. Cell Biol. 142, 499-509.

Uriu, Y., Kiyonaka, S., Miki, T., Yagi, M., Akiyama, S., Mori, E., Nakao, A., Beedle, A. M., Campbell, K. P., Wakamori, M., and Mori, Y. (2010). Rab3-interacting molecule g isoforms lacking the Rab3-binding domain induce long-lasting currents but block neurotransmitter vesicle-anchoring in voltagedependent P/Q-type $\mathrm{Ca}^{2+}$ channels. J. Biol. Chem. 285, 21750-21767.

Valdez, G., Tapia, J. C., Kang, H., Clemenson, G. D. Jr., Gage, F. H., Lichtman, J. W., and Sanes, J. R. (2010). Attenuation of age-related changes in mouse neuromuscular synapses by caloric restriction and exercise. Proc. Natl. Acad. Sci. U.S.A. 107, 14863-14868.

Verstreken, P., Koh, T. W., Schulze, K. L. Zhai, R. G., Hiesinger, P. R., Zhou, Y., Mehta, S. Q., Cao, Y., Roos, J., and Bellen, H. J. (2003). Synaptojanin is recruited by endophilin to promote synaptic vesicle uncoating. Neuron 40, 733-748.

Wagh, D. A., Rasse, T. M., Asan, E., Hofbauer, A., Schwenkert, I., Durrbeck, H., Buchner, S., Dabauvalle, M. C., Schmidt, M., Qin, G., Wichmann, C., Kittel, R., Sigrist, S. J., and Buchner, E. (2006). Bruchpilot, a protein with homology to ELKS/CAST, is required for structural integrity and function of synaptic active zones in Drosophila. Neuron 49, 833-844.

Wairkar, Y. P., Toda, H., Mochizuki, H., Furukubo-Tokunaga, K., Tomoda, T., and Diantonio, A. (2009). Unc51 controls active zone density and protein composition by downregulating ERK signaling. J. Neurosci. 29, 517-528.

Walrond, J., and Reese, T. (1985). Structure of axon terminals and active zones at synapses on lizard twitch and tonic muscle fibers. J. Neurosci. 5, 1118-1131.

Wanaverbecq, N., Bodor, A. L., Bokor, H., Slezia, A., Luthi, A., and Acsady, L. (2008). Contrasting the functional properties of GABAergic axon terminals with single and multiple synapses in the thalamus. J. Neurosci. 28, 11848-11861.

Wang, P., Yang, G., Mosier, D. R., Chang, P., Zaidi, T., Gong, Y. D., Zhao, N. M., Dominguez, B., Lee, K. F., Gan, W. B., and Zheng, H. (2005). Defective neuromuscular synapses in mice lacking amyloid precursor protein (APP) and APP-Like protein 2. J. Neurosci. 25, 1219-1225.

Wang, X., Hu, B., Zieba, A., Neumann, N. G., Kasper-Sonnenberg, M., Honsbein, A., Hultqvist, G., Conze, T., Witt, W., Limbach, C., Geitmann, M., Danielson, H., Kolarow, R., Niemann, G., Lessmann, V., and Kilimann, M. W. (2009a). A protein interaction node at the neurotransmitter release site: domains of Aczonin/Piccolo, Bassoon, CAST, and Rim converge on the N-terminal domain of Munc13-1. J. Neurosci.29, 12584-12596.

Wang, Z., Wang, B., Yang, L., Guo, Q., Aithmitti, N., Songyang, Z., and Zheng, H. (2009b). Presynaptic and postsynaptic interaction of the amyloid precursor protein promotes peripheral and central synaptogenesis. J. Neurosci. 29, 10788-10801.

Wang, Y., Liu, X., Biederer, T., and Südhof, T. C. (2002). A family of RIM-binding proteins regulated by alternative splicing: implications for the genesis of synaptic active zones. Proc. Natl. Acad. Sci. U.S.A. 99, 14464-14469.

Wang, Y., Okamoto, M., Schmitz, F., Hofmann, K., and Südhof, T. C. (1997). Rim is a putative Rab3 effector in regulating synaptic-vesicle fusion. Nature 388, 593-598.

Wichmann, C., and Sigrist, S. J. (2010). The active zone T-bar - a plasticity module? J. Neurogenet. 24, 133-145.

Wyatt, R. M., and Balice-Gordon, R. J. (2008). Heterogeneity in synaptic vesicle release at neuromuscular 
synapses of mice expressing synaptopHluorin. J. Neurosci. 28, 325-335.

Xie, W., Stribley, J. A., Chatonnet, A., Wilder, P. J., Rizzino, A., Mccomb, R. D., Taylor, P., Hinrichs, S. H., and Lockridge, O. (2000). Postnatal developmental delay and supersensitivity to organophosphate in gene-targeted mice lacking acetylcholinesterase. J. Pharmacol. Exp. Ther. 293, 896-902.

Xu-Friedman, M. A., Harris, K. M., and Regehr, W. G. (2001). Threedimensional comparison of ultrastructural characteristics at depressing and facilitating synapses onto cerebellar Purkinje cells. J. Neurosci. 21, 6666-6672.

Yeh, E., Kawano, T., Ng, S., Fetter, R., Hung, W., Wang, Y., and Zhen, M. (2009). Caenorhabditis elegans innexins regulate active zone differentiation. J. Neurosci. 29, 5207-5217.

Yeow, M. B., and Peterson, E. H. (1991). Active zone organization and vesicle content scale with bouton size at a vertebrate central synapse. J. Comp. Neurol. 307, 475-486.

Zenker, M., Aigner, T., Wendler, O., Tralau, T., Muntefering, H., Fenski, R., Pitz, S., Schumacher, V., Royer-Pokora, B., Wuhl, E., Cochat, P., Bouvier, R., Kraus, C., Mark, K., Madlon, H., Dotsch, J., Rascher, W., Maruniak-Chudek, I., Lennert, T., Neumann, L. M., and Reis, A. (2004a). Human laminin beta2 deficiency causes congenital nephrosis with mesangial sclerosis and distinct eye abnormalities. Hum. Mol. Genet. 13, 2625-2632.

Zenker, M., Tralau, T., Lennert, T., Pitz, S., Mark, K., Madlon, H., Dotsch,
J., Reis, A., Muntefering, H., and Neumann, L. M. (2004b). Congenital nephrosis, mesangial sclerosis, and distinct eye abnormalities with microcoria: an autosomal recessive syndrome. Am. J. Med. Genet. A 130A, 138-145.

Zhai, R. G., and Bellen, H. J. (2004). The architecture of the active zone in the presynaptic nerve terminal. Physiology (Bethesda) 19, 262-270.

Zhang, L., Volknandt, W., Gundelfinger, E. D., and Zimmermann, H. (2000) A comparison of synaptic protein localization in hippocampal mossy fiber terminals and neurosecretory endings of the neurohypophysis using the cryo-immunogold technique. J. Neurocytol. 29, 19-30.

Conflict of Interest Statement: The authors declare that the research was conducted in the absence of any commercial or financial relationships that could be construed as a potential conflict of interest.

Received: 07 December 2011; accepted: 30 January 2012; published online: 15 February 2012.

Citation: Clarke GL, Chen $J$ and Nishimune H (2012) Presynaptic active zone density during development and synaptic plasticity. Front. Mol. Neurosci. 5:12. doi: 10.3389/fnmol.2012.00012 Copyright (c) 2012 Clarke, Chen and Nishimune. This is an open-access article distributed under the terms of the Creative Commons Attribution Non Commercial License, which permits noncommercial use, distribution, and reproduction in other forums, provided the original authors and source are credited. 